\title{
Die politieke aktivisme van Birgitta Birgersdotter (1302/3-1373)
}

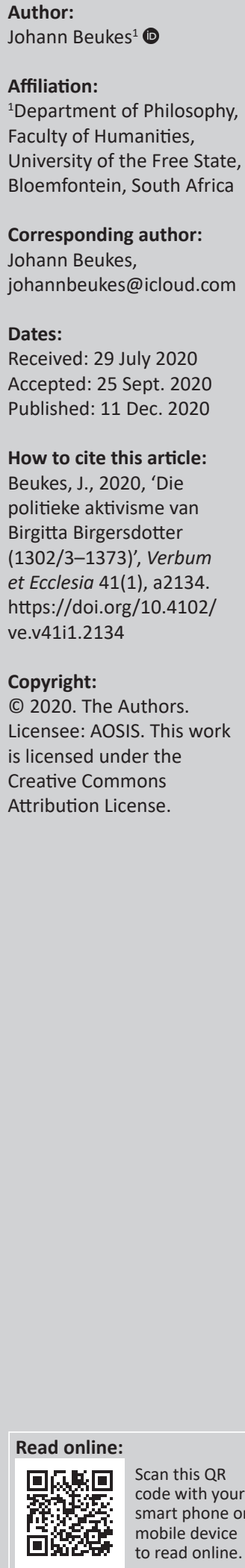

The political activism of Birgitta Birgersdotter (1302/3-1373). The objective of this article is to illuminate the political thought of the Swedish Medieval thinker and mystic, Birgitta Birgersdotter (1302/3-1373; Birgitta of Sweden, Brigida Suecica), on the basis of an unprecedented acceleration in the specialist research over the past two decades, including significant expositions by Unn Falkeid, Bridget Morris, Maria Oen, Claire Sahlin, Päivi Salmesvuori and Jonathan Adams. When these recent outputs are disseminated and juxtaposed, Birgitta can be profiled as a political activist who, against all conventions and with significant self-exposure from 1349 to 1373, presented a fierce critique of both the Avignon Papacy (1309-1370) and secular forms of government in Sweden, France, England and Italy. Her political engagements, spread throughout her eight-volume Liber celestis revelaconium, bear witness to a first-hand experience of and profound insight in the complex intrigues between the church, nobility and sovereigns in the second half of the 14th century. Her understanding of the established political and theological-philosophical traditions of the Middle Ages made possible a thorough criticism of the abuse of political power, be it by the pope, king or emperor. Birgitta's relentless attempts to reclaim Rome as the political and religious centre of 14th-century Christendom, her unrestrained critique of papal excesses at Avignon and her urgent calls to the general reform of the church take central stand in this political activism. As the specialist research continues to open up the legacy of this still underrated female thinker from the Middle Ages, Birgitta is placed in our midst as a crucial voice of dissent in the anarchistic contexts of the 14th century.

Intradisciplinary and/or interdisciplinary implications: As a millennium-long discourse, Medieval philosophy functions in a Venn diagrammatical relationship with Medieval history, Church history, patristics and philosophy of religion. Whenever 'mainstream' or 'canonised' Medieval philosophy is impacted by the specialist research, it may well have implications that these closely related disciplines could take note of. Such is the case in this reappraisal of the life and work of Birgitta of Sweden.

Keywords: Birgitta Birgersdotter; Birgitta of Sweden (1302/3-1373); Unn Falkeid; Liber celestis revelaconium I-VIII; Bridget Morris; Maria Oen; Claire Sahlin; Päivi Salmesvuori; Denis Searby; Cornelia Wolfskeel.

Nata est Birgero quedam filia, cuius vox admirabilis audietur per mundum. ${ }^{1}$

\section{'n Unieke politieke denker uit Swede in die latere Middeleeue}

Die oogmerk van hierdie artikel is om die politieke denke van die Sweedse Middeleeuse aktivis Birgitta Birgersdotter² (1302/3-1373; ook 'Birgitta van Swede'), met 'n bywerking van die mees onlangse nisuitsette ${ }^{3}$ in 'n ongekende vaartversnelling in die spesialisnavorsing oor die afgelope dekade, te ontleed. Die artikel is beskrywend analities in die aanbod van die relevante ideëgeskiedenis en sinteties in 'n samehangende byeenbring van die mees resente sekondêre tekste.

1. Vir Birgerus is ' $n$ dogter gebore wie se aangrypende stem oor die wêreld gehoor sal word', hoofmonnik Petrus Olafsson (in Collijn [red. 1924-1931]:75; per Sahlin 2001:13).

2.Die leidinggewende Birgitta-ondersoeker Oen (2019:1-2) se advies om eietyds biografies na Birgitta te verwys na sowel haar noemnaam (Birgitta) as haar oorspronklike Sweedse dogtersnaam (Birgersdotter), aanvullend tot die gekanoniseerde (1391) 'Birgitta van Swede' en 'Brigida Suecica', word hier met instemming gevolg. Die konvensie in Middeleeuse navorsing om na Middeleeuse skrywers (waar paslik en moontlik) per voornaam te verwys, word daarby gehandhaaf.

3.Adams (2016:3-12); Andersson (red. 2011:1-5, 2019:159-185); Debby (2019:223-246); Falkeid (2017:95-120, 2019:80-102); Frediksson (2019:103-131); Fritz (2019:132-158); Hutchison (2019:269-288); Luongo (2019:25-52); Morris (2006:3-38); Oen (2019:1-24); Piltz (2019:53-79); Rychterová (2019:247-268) en Salmesvuori (2014:1-22); vergelyk ook die betreklik gedateerde maar steeds relevante bydraes in Holloway (1992:3-12); Morris (1999:2-12); Morris en O'Mara (2000:1-24); Sahlin (2001:13-33); Straubhaar (2002:309-318) en Wolfskeel (1989:191-122). 
'n Afgestorwe leek uit die Sweedse adelstand, wat haar geboorteland 42 jaar vantevore as weduwee verlaat het om met sonderlinge politieke aktivisme in Rome bekendheid en inderdaad berugtheid te verwerf, word op 07 Oktober 1391 deur Pous Bonifatius IX (1350-1404, Pietro Tomacelli, tweede pous van Rome [1389-1404] tydens die Groot Verdeling [1378-1417]), tot heilige van die kerk gekanoniseer. 'n Literatuurkorpus, bestaande uit agt volumes en bykans 700 afdelings, getitel Liber celestis revelaconium (Birgersdotter 2006, 2008, 2012, 2015) en geredigeer deur haar twee biegvaders met identies dieselfde voorname en vanne, hoofmonnik Petrus Olafsson van Alvastra (gest. 1390) en magister Petrus Olafsson van Skänninge (gest. 1378) het as deposisie of motivering vir die kanonisering van Birgitta Birgersdotter, toe reeds ook 'Birgitta van Swede' of 'Brigida Suecica' genoem, gedien (Adams 2016:4; Oen 2019:1). Die biografiese aantekeninge of vita wat deur die twee biegvaders in hulle motiverings ter kanonisering verskaf is, is tot vandag toe die enigste bronne vir die oorsig van die lewe van hierdie unieke vroulike denker uit die latere Middeleeue en die enigste Middeleeuse mistikus wat uit Swede na vore getree het. Birgitta is ook die enigste Sweed wat tot op hede deur die kerk gekanoniseer is (Adams 2016:1).

Liber celestis revelaconium (Die hemelse boek van openbaringe, [Birgersdotter 2006, 2008, 2012, 2015], van hier af ' $L C R^{\prime}$ ) is deur die twee Olafssons byeengebring in sowel die oorspronklike Latynse teks (cf. Straubhaar 2002:309-318) en daarna in verskeie Europese volksvertalings versprei. Die bykans 700 mistieke 'openbaringe' in LCR word aangebied as direk van God (die Vader), Jesus Christus, Maria en verskeie gekanoniseerde heiliges van die kerk ontvang (of as meganies geïnspireerd beskou), met die bedoeling om die opbou van die kerk te dien en die getraumatiseerde mensheid van die 14de eeu opnuut tot verlossing in Christus te begelei. Op kenmerkend uitdagende wyse raak die inhoud van hierdie openbaringe oop senuweepunte in die onstuimige 14de-eeuse politiek en teologie aan: die Groot Verdeling self, met die pousdom op die punt om in twee (in 1378, tussen Avignon en Rome) geskeur te word (cf. Rollo-Koster 2015:239-282), die Honderdjarige Oorlog (1337-1453) tussen die koningshuise van Plantagenet in Engeland en Valois in Frankryk oor die legitieme monargie van Frankryk, die jammerlike agteruitgang van die priesterlike amp, die gebrek aan 'n 'gestuurde' of apostolêre lewe, die vraag na die maagdelike geboorte, die outentisiteit van relieke en die status van die sakrament van die nagmaal, om slegs enkele temas in $L C R$ te noem. Die status en geldigheid van $L C R$ is na Birgitta se kanonisering gedebatteer by verskeie konsilies (in besonder by Konstans [1414-1418] en Basel [1431-1449]; sien Frediksson [2019:103-131] en in sowel kerklike - as lekekringe bestudeer oor die hele Europa heen, insluitende kloosters, universiteite, die opkomende humanistiese kringe en proto-Reformatoriese groeperinge [Oen 2019:1]). Die vraag is hoe 'n vroulike leek uit die noordelike uithoeke van Europa so 'n merkwaardige politieke invloed op soveel verskillende milieus in die latere Middeleeue kon uitoefen. Die antwoord is na hierdie lesing in Birgitta se politieke aktivisme terug te vind.
Birgitta is in die winter van $1302 / 3$ as een van sewe kinders vanuit 'n aristokratiese familie naby eietydse Norrtälje in Swede, gebore. Haar vader, Birger Petersson (gest. 1327), was 'n afstammeling van koning Sverker I (gest. 1156), geslane ridder en laghman (geregsdienaar of regsbeampte), wat 'n gedokumenteerde bydrae gelewer het tot die kodifisering van Laat-Middeleeuse wetgewing in die provinsie Uppland (die Upplandslagen). Haar moeder weer, Ingeborg Bengtsdotter (gest. 1314), was 'n direkte afstammeling van die koninklike Folkung-dinastie. Birger se gesiene familie was deeglik geanker in die godsdienstige lewe van Laat-Middeleeuse Sverige: talle familielede was biskoppe en uitvoerende hoofde van kerklike skole, terwyl 'n aartsbiskop en katedraal-provoos ook uit hierdie diep godsdienstige familie na vore getree het (Adams 2016:5). Die godsdienstige toewyding van die familie spreek ook daaruit dat Birger 'n pelgrimsreis na die pelgrimsentrum Santiago de Compostela in Spanje onderneem het, juis in die plofbare dekade van die 1320's (met talle Franciskane, waaronder Willem van Ockham [ca. 1285-1349], wat in hierdie tyd geëekskommunikeer is deur pous Johannes XXII), op pad waarheen Birger ook die pouslike setel te Avignon in Frankryk besoek het - 'n kritiese gebeurtenis wat Birgitta se pro-Rome beskouinge dekades later sou beïnvloed. $\mathrm{Na}$ haar moeder se voortydige dood is Birgitta deur haar tante, Katarina Bengtsdotter, in Aspenäs opgevoed totdat die voornemende non as dertienjarige kind teensinnig in 'n gereëlde huwelik bevestig is met Ulf Gudmarsson in 1316. Agt kinders is uit die huwelik gebore, waarvan 'n dogter, ook Katarina (gest. 1381), vir die res van Birgitta se lewe 'n versorgende teenwoordigheid sou wees (Morris 1999:32, 41).

Gedurende die vroeë 1330's word Birgitta opgeroep om aan die Sweedse hof van die pas gekroonde koningin, Blanche van Namur (gest. 1363), die dogter van 'n Vlaamse hertog, as onderwyseres te dien. 'n Dekade later vergesel sy haar eggenoot op 'n pelgrimsreis na Santiago de Compostela, op dieselfde roete as wat haar vader twee dekades vantevore gevolg het. Tydens die pelgrimsreis word Ulf Gudmarsson siek en sterf kort na die egpaar se terugkoms in Swede in die siekeboeg van die Cistersiaanse klooster in Alvastra (Sahlin 2001:16 [vn.13]). Direk na haar eggenoot se dood doen Birgitta afstand van haar boedel en tree tot die gewyde lewe van die Cistersiaanse kloosterwese toe, sonder om aansoek te doen om as non toegelaat te word: sy het waarskynlik toe reeds haar jeugdige ideaal om 'n non te word op grond van ouderdomsoorwegings agtergelaat (Adams 2016:6; Morris 1999:72). Binne weke daarna ervaar Birgitta 'n eerste of roepingsvisioen, waarin sy beweer dat sy deur God geroep is om as bruid (sponsa) van Christus en as instrument (canale) van die Heilige Gees te dien (Salmesvuori 2014:63-65). Self aanvanklik verskrik gelaat deur hierdie mistieke ervaring, deel Birgitta die inhoud van die roepingsvisoen met die uitvoerende hoof van Linköping-katedraal, Mathias Öviddson (gest. 1350), wat die verantwoordelikheid opneem om haar biegvader te word en haar aanmoedig om 'n eie kloosterkompleks wat uitdruklik voorsiening maak vir 'n nonnevleuel, te stig en ontwikkel (sien LCR I:81:18, 'Instruksies vir die bou van die klooster'). Birgitta stig die 
Ordo Sanctissimi Salvatoris gevolglik in 1346, met sowel koninklike sanksie as 'n bruidskat in die vorm van 'n landgoed te Vadstena, waarop die kloosterperseel ontwikkel is. In 1347, met die swart pes wat elders oor die Europese kontinent swiep en waarvan Swede nie vir lank gespaar sou bly nie, word die Vadstena-klooster ingewy. Onder die vernietigende aanslag van die pes onderneem Birgitta in 1349, met bystand van haar dogter Katarina en 'n klein entourage, ' $n$ pelgrimsreis na Rome. Sy voel haar by aankoms in Rome geroepe om midde die politieke en teologiese krisisse van die middel-14de eeu egter in die stad te bly en nie terug te keer Swede toe nie (Adams 2016:7). Sy sou tot en met haar dood in 1373 in Rome bly woon en werk, slegs onderbreek deur 'n lang pelgrimsreis na Jerusalem in die laaste twee jaar van haar lewe (waartydens sy die drie belangrikste langafstand-pelgrimsreise - die peregrinationes maiores - na Santiago de Compostela, Rome en Jerusalem voltooi het) en korter reise onderneem na ander pelgrimbakens in Italië self, in besonder in Milaan, Pavia, Assisi, Ortona, Bari, Benevento, Salerno en Amalfi (Adams 2016:7).

Birgitta se verblyf van 24 jaar in Rome is gekenmerk deur 'n politieke aktivisme, waarin sy die staat sowel as die kerk openlik gekonfronteer het met die 'algehele en anargistiese agteruitgang van die 14de-eeuse Europese samelewing' (Beukes 2020c:6). Die teologiese trant van haar bykans 700 openbaringe kan as 'hervormend' en selfs as 'protoReformatories' beskryf word (Morris 1999:122), in die sin dat sy alle vlakke van die samelewing profeties krities aangespreek het, maar veral die kerklui en adel verantwoordelik gehou het vir sodanige disintegrasie van die maatskaplike leefwêreld. Daarby het sy haar met aansienlike blootstelling en selfprysgawe beywer vir die herstel van die pouslike setel vanaf Avignon terug na Rome (Salmesvuori 2014:127,174). Na haar afsterwe op 23 Julie 1373 is Birgitta aanvanklik in San Lorenzo in die Panisperna in Rome begrawe, hoewel haar oorskot twee jaar later in Vadstena herbegrawe is (Morris 1999:141-142). Ten spyte van haar uitgesproke politieke aktivisme is die klooster in Vadstena in 1370 deur pous Urbanus V voorwaardelik goedgekeur, as 'n legitieme kerklike klooster in 1375 deur pous Gregorius XI gevestig en het die Ordo Sanctissimi Salvatoris vyf jaar na Birgitta se dood volle pouslike sanksie (deur Urbanus VI op 03 Desember 1378) ontvang (Adams 2016:8 [vn.32]).

\section{Die vaartversnelling in die onlangse Birgitta-navorsing}

Hoewel daar sporadiese uitsonderinge was, kan die Birgittanavorsing tot betreklik onlangs as oorwegend Sweeds of minstens Skandinawies in sosiolinguistiese oriëntasie en vakkundig eerder filologies as filosofies beskryf word. Liber celestis revelaconium is as platform vir onder meer Sweedse taalhistoriese studies en vertalingsmetodologie gebruik, terwyl die omvangryke literatuur wat by die Vadstenaklooster geproduseer en gedissemineer is steeds beskou word as die kern van die Middeleeuse Sweedse korpus, met inbegrip van die neerslag daarvan in Oud-Deense en Middel-
Noorweegse tekste. Ook in die kommentare wat LCR inderdaad is filosofies geanaliseer het, tot nog in die voorlaaste dekade van die 20ste eeu, is in Sweeds aangebied (bv. deur Klockars 1966, 1971, 1976). Synde feitlik uitsluitlik Skandinawies, was die tempo van die Birgitta-navorsing tot in die 1990's gevolglik stadig en afgemete (vgl. Sahlin 2001:viii-ix). Birgitta-studies is egter binne die groter konteks van gespesialiseerde navorsing oor vroulike Middeleeuse denkers, in 1989 vir die eerste keer van impetus voorsien met die (onverwagse) opname van 'n Birgitta-afdeling in die gevierde redaksionele werk van Mary Ellen Waithe (cf. Wolfskeel 1989:191-122). Met hierdie toeganklike aanbod in Engels is Birgitta naas ander vroulike denkers uit die Middeleeue wat tot in daardie stadium betreklik onbekend en ongetwyfeld ondergekommentarieerd was, in die soeklig gebring; dit geld in besonder vir Héloïse d'Argenteuil (ca.1100-1164, cf. Beukes 2019b:1-12), Hildegard von Bingen (1098-1179; cf. Beukes 2019a:64-102), Mechtild von Magdeburg (ca.1207-ca.1282; cf. Beukes 2019b:1-12), Hadewijch van Antwerpen (fl. 1240; cf. Beukes 2020b:1-10), Marguerite Porete (ca. 1250-1310; cf. Beukes 2020d:1-3), Juliana van Norwich (1342-ca.1416; cf. Beukes 2020e:1-10) en Katharina van Siena (1347-1380; cf. Beukes 2021:1-3). Wolfskeel se tydige bydrae het feitlik onmiddellik tot 'n oplewing in die navorsing buite Skandinawië aanleiding gegee: Waar daar voor 1989 kwalik enigiets oor Birgitta buite Swede beskikbaar was, verskyn binne 'n jaar daarna 'n eerste vertaling van afdelings van $L C R$ in Engels (met inleiding en kommentaar; sien Holloway 1992), asook 'n eerste redaksiewerk in Engels (sien Kezel [red. 1990]), wat juis 'n filoloog, bedrewe in sowel Latyn as Sweeds, Bridget Morris, daartoe gebring het om later dieselfde dekade die eerste grondige monografie oor Birgitta in Engels te publiseer (Morris 1999).

Morris volg hierdie eerste Engelse monografie op met 'n omvattende projek om al agt volumes van $L C R$ (Birgersdotter 2006, 2008, 2012; vir 'n navorsingsverantwoording, sien Morris 2006:3-8), asook Birgitta se kleiner werke (Birgersdotter 2015), met behulp van vertalings uit Latyn na Engels deur die bekwame latinis Denis Searby deeglik in te lei en met inbegrip van die ou Sweedse leestradisie (cf. Collijn [red. 1924-1931]) te herkommentarieer. Vir die eerste keer is die volle Birgitta-korpus daarmee in Engels beskikbaar gestel. Morris se monografie en haar en Searby se gesamentlike vertalingsprojek het die deur geopen vir wat duidelik begin dui het op ' $n$ tempoversnelling in die Birgittanavorsing. ' $n$ Tweede Engelse monografie deur Claire Sahlin volg naamlik in 2001. 'n Jaar daarna volg 'n redaksionele werk met fokus op vroulike denkers vanuit die Middeleeue wat uitsluitlik in Latyn geskryf het en nou verrassend ook vir ' $n$ afdeling oor Birgitta voorsiening maak (Straubhaar 2002:309-318). Met die klein navorsingsgemeenskap deeglik bewus van Morris en Searby se voortgaande vertalingskedule, verskyn 'n redigering en vertaling van die ordereëls van die Vadstena-klooster in 2011 (met inleiding en kommentaar, Andersson [red. 2011]), 'n monografie deur Salmesvuori (2014) wat die verhouding tussen mag en kanonisering met behulp van Birgitta se politieke aktivisme as gevallestudie 
ontleed, en 'n uitstaande proefskrif deur Jonathan Adams by University College London, onder aanvanklike promotorskap van Bridget Morris, wat uiteindelik as 'n monografie deur Brill in Leiden uitgegee is (Adams 2016:xi).

Na Wolfskeel se boekhoofstuk in 1989 was daar dus 'n opwaartse kurwe in hierdie nis wat voorheen as uitsluitlik van belang vir Skandinawiese studies geag is, met Holloway se vertaling, Kezel se redaksiewerk, Morris en Sahlin se monografieë, Morris en Searby se redigering en vertaling van die volledige $L C R$, Straubhaar se ontleding van die kwaliteit van die Latynse tekste, die vertalings van die kloostertekste deur Andersson, Salmesvuori se monografie en Adams se gepubliseerde proefskrif. Dit dui op nege omvangryke en snel opeenvolgende bydraes oor 'n denker wat tot in die laat1980's effektief afwesig was in die internasionale navorsing, wat ook verklaar waarom Brigitta tot op hede in geen Engelse, Duitse, Franse en Nederlandse inleidingswerk tot Middeleeuse filosofie opgeneem is nie. Birgitta het inderdaad nie 'n bydrae tot die skolastiek of tot die Laat-Middeleeuse filosofiese indeksering van kosmologie, epistemologie, metafisika en psigologie gemaak nie; haar politieke denke sou wel onder die vyfde afdeling van etiek tuisgebring kon word, siende dat politieke teorie op Aristoteliese gronde in die latere Middeleeue konsekwent onder etiek hanteer is (bv. by Johannes van Salisbury; sien Beukes 2019d:1-3). Dit is juis die nie-skolastiese styl en onkonvensionele inhoud van $L C R$ wat Birgitta in die filosofiese gemeenskap se midde stel as 'n aweregse Middeleeuse denker: die gebrek aan Birgittainskrywings in Middeleeuse inleidingswerke en bloemlesings is teen hierdie agtergrond begryplik. ${ }^{4}$

Die hoogtepunt van die vaartversnelling in die navorsing oor die afgelope twee dekades word egter gevind in 'n eerste omvattende inleidingswerk oor Birgitta se historiese konteks en uitsette as 14de-eeuse politieke en teologiese skrywer, getitel A companion to Birgitta of Sweden and her legacy in the later Middle Ages, gepubliseer in 2019 onder redaksie van Maria Oen by Brill te Leiden, in die reeks Brill's Companions to the Christian Tradition. In hierdie werk word dit

4.'n Vergelykende studie van die relevante inleidingstekste wys die volgende uit: die filosofiese woordeboek van Brown en Flores (2007) bevat geen verwysing na Birgitta nie, hoewel in die werk wel 'n kort afdeling ingeruim is oor Juliana van Norwich (2007:194), wat nie minder ondergekommentarieerd as Birgitta was to (ook) in die laaste dekades van die 20ste eeu nie (cf. Beukes 2020e:3); die tweede volume van Pasnau en Van Dyke (reds. 2010b:885) se omvattende redaksiewerk bevat in die outeurslys oor Heymerik van de Velde ' $n$ verwysing van een sin na Heymerik se verdediging van Birgitta se $L C R$ met geen verwysing na Birgitta in die Herste volume eerste volume van hierdie omvattende dubbel-volume redaksiewerk nie (red. Pasnau \& Van Dyke 2010a); die omvangryke ensiklopedie van Lagerlund (red. 2011:474) bevat ook slegs binne die bespreking van Heymerik van de Velde ' $n$ verwysing van slegs een sin; ook McGrade (red. 2003) se omvattende en andersin hoogs insluitende redaksiewerk bevat geen verwysing nie. Die volgende ande insluitende inleidingswerke en redaksiewerke bevat geen verwysings na Birgitta nie Beukes (2020a); Bosley en Tweedale (reds.] 2004), Copleston (1993); Gracia en Noone (reds. 2006); Grant (2004); Hyman, Walsh en Williams (reds. 2010); Kenny (2005); Kretzmann, Kenny en Pinborg (reds. 1982); Luscombe (1997); Martin (1996) Ook nie een van Marenbon se drie omvattende oorsigwerke (1991, red. 1998, 2007) bevat selfs ' $n$ indirekte verwysing nie. Met ander woorde: in die hoofstroom-oorsig en -inleidingsliteratuur, dus buite die gespesialiseerde (Sweedse) Birgitta-navorsing, bestaan daar geen werke oor die afgelope drie dekades (1990-2020) wat wel na haar persoon en werk verwys nie, uitgesonder die twee verwysings na Heymerik van de Velde se verdediging van $L C R$. Selfs werke waarvan verwag sou kon word dat daar wel 'n verwysing sou wees op grond van die andersins hoogs insluitende aard daar wel ' $n$ verwysing sou wees op grond van die andersins hoogs insluitende aard daarvan, soos die van Beukes (wat wel ses ander Middeleeuse vroulike denkers grondig bespreek), Gracia en Noone, Lagerlund, Marenbon en McGrade, gaan by Birgitta verby. Dit word nie as ' $n$ klag voor die inleidingsnavorsing gestel nie, maa aangedui as juis die natuurlike gevolg daarvan dat Birgitta se persoon en werk to heel onlangs nog op die Skandinawiese marges van navorsing in Middeleeuse filosofie verkeer het en eers vanuit die onlangse vaartversnelling in die internasionale navorsing oopgedek is. duidelik dat die navorsing vinnig en ver gereis het sedert Wolfskeel se enigmatiese boekhoofstuk in 1989. Tien spesialiste vanuit 'n verskeidenheid deeldissiplines lewer unieke bydraes tot hierdie bundel, waarmee die eietydse Birgitta-navorsing (waarvan hierdie artikel sprekend is) van konkrete impetus voorsien word: afgesien van Oen (2019) se inleidingshoofstuk, bied Andersson (red. 2019:159-185) 'n homiletiese en retoriese ontleding van preektekste by die Vadstena-klooster aan (ongeveer 150 manuskripte is ter sprake), soos wat dit deur monnike van die klooster verwerk is vanuit LCR. Debby (2019:223-246) se bydrae, fokus dit op die filosofiese nawerking van Birgitta se werke in Toskaanse kuns en die groter estetiese konteks van die Renaissance. Falkeid (2019:80-102) se bydrae is uitsluitlik gerig op die dramaties uitdagende kwaliteite van Birgitta se politieke diskoers, aangevul deur Frediksson (2019:103-131) se ontleding van die evaluering van $L C R$ by die konsilies van Konstans (1414-1418) en Basel (1431-1449), wat nie minder polemies en veglustig was as Birgitta self nie. Rychterová (2019:247-268) se ideëhistoriese analise van die interpretasie van $L C R$ in die wyer konteks van die Heilige Romeinse Ryk vind nou hierby aansluiting. Fritz (2019:132-158) bied 'n gedetailleerde ontwikkelingsgeskiedenis van die Vadstenaklooster aan, met bykomende aandag aan meditatiewe praktyke binne die betrokke klooster. Hutchison (2019: 269-288) fokus op die Engelse resepsie van LCR en in watter mate daar kruisbestuiwing tussen Oos-Anglia en Swede rondom die middel van die 14 de eeu bestaan het. Luongo (2019:25-52) problematiseer die opvatting van 'die outeur' en 'outeurskap' in Middeleeuse mistieke literatuur en gebruik Birgitta en LCR in hierdie opsig as gevallestudie. Die enigste bydrae wat op die teologiese inhoude en kwaliteite van Birgitta se uitset fokus, is dié van Piltz (2019:53-79), wat ook die mate waarin Birgitta wel met skolastiese teologie in verbinding getree het, ondersoek. Piltz se bydrae verskaf ook 'n uitstekende oorsig van Klockars $(1966,1971,1976)$ se baanbrekerswerk in Sweeds, voordat enige teks van of oor Birgitta buite Skandinawië betekenisvolle aandag geniet het.

In navorsing in Middeleeuse filosofie is dit hoogs buitengewoon, selfs in terme van die 'gekanoniseerde' denkers (Beukes 2019d:1-3), dat 'n volle korpusvertaling (Morris en Searby, cf. Birgersdotter 2006, 2008, 2012, 2015), twee gedeeltelike vertalings (red. Andersson 2011; Straubhaar 2002), vier monografieë (Adams 2016; Morris 1999; Sahlin 2001; Salmesvuori 2014) en 'n gespesialiseerde redaksionele werk Oen [red. 2019]) binne slegs twee dekades die lig sien. Trouens, selfs al sou hierdie uitset oor ' $n$ tydperk van vier dekades plaasgevind het, sou dit ewe merkwaardig gewees het, juis omdat navorsing in Middeleeuse filosofie teen so 'n geduldige pas geskied. Wanneer hierdie soort vaartversnelling in die navorsing sigbaar word, verdien dit 'n grondige bywerking en bespreking van die aanloop en inhoude van sodanige versnelling, teen die agtergrond van die vraag of sodanige uitset die vermoë het om die Middeleeuse 'kanon' te konfronteer en te verruim (cf. Beukes 2019d:3-4). Dit word daarmee ook moontlik om Birgitta se politieke 
aktivisme grondig aan die hand van die mees onlangse spesialisnavorsing te profilieer. ${ }^{5}$

\section{Birgitta se politieke aktivisme}

Wat behels Birgitta se politieke denke dus - en waarom behoort dit juis as 'aktivisties' beskryf te word? 'Politieke aktivisme' dui in Laat-Middeleeuse konteks op 'n provokatiewe uitdaging van die kerklike en/of sekulêre leierskap, met inbegrip van die reële lewensgevaar waarin dit die betrokke aktivis gestel het (vgl. Wolfskeel 1989:191-192). Johannes van Salisbury (ca. 1115-1180), se ‘Vermoor die tiran!' in Policraticus (1159; Beukes 2019d:7) en Birgitta se Italiaanse tydgenoot Katharina van Siena (1347-1380; Beukes 2021:7) se fel kritiek teen die pousdom is bekende voorbeelde van sodanige politieke aktivisme in die Middeleeue. Die relevante afdelings in Birgitta se $L C R$ maak dit van meet af duidelik dat politieke kommentaar vir haar geen afstandelike en gespesialiseerde onderneming is nie, maar die integrale eienskap van 'n aktiewe en dienende lewe binne die openbare lewe en daarom die politieke arena - en juis ook sprekend van 'n lewe toegewy aan God. Politieke filosofie verskaf die medium waarvolgens die goeie vir beide, die enkeling en gemeenskap, gerealiseer kan word. Birgitta betoog dat die openbare sfeer nie spontaan of van nature korrup is nie, maar wanneer korrupsie wel voorkom, dit ondersoek, gekritiseer, gekorrigeer en - indien dit daarop aankom vernietig moet word, ten einde geregtigheid en die goeie binne die politieke gemeenskap te laat seëvier. Hieronder sal aangedui word dat Birgitta haar reputasie as 'n beskermdame van Middeleeuse politieke filosofie, as 'n ontwikkelende vakgebied in die buite-skolastiese domeine van die Middeleeuse Weste, verdien.

\section{Birgitta se politieke teiken: Die pouslike setel in Avignon}

Ons sou egter met Birgitta se politieke denke nie kon vorder alvorens die historiese dekor daarvan opgestel is nie, naamlik die ontwikkelinge by die Roomse curia in Avignon vanaf 1309 tot 1417 (vir Clemens VI se termyn 1342-1352, sien Rollo-Koster 2015:70-72; vir wyer oriëntasie, 1-14; 24-31). Sedert 1309 was die pousdom in selfopgelegde ballingskap nadat pous Clemens V (dus te onderskei van Clemens VI, 1264-1314, Raymond Bertrand de Got, pous vanaf 1305 tot 1314) die setel in Rome ontruim en na die pouslike perseel in Comtat Venaissin in Provence verskuif het, op grond van (soms oordrewe bewerings van) politieke onstabiliteit in Rome. Die hoofstad van Provence, Avignon, was 'n beskermstad van die koningshuis van Anjou, wat lojaal teenoor Clemens V gestaan het. Daarby was die ligging van die setel in Avignon gunstig vir die hantering van die dreigende oorlog tussen Frankryk en Engeland, wat inderdaad in 1337 die Honderdjarige Oorlog tussen die twee lande sou inisieer. Boonop was Avignon strategies geplaas op

5.Birgitta se invloed op vroulike denkers van die Renaissance word tans ook in " $\mathrm{n}$ interdissiplinêre projek (2018-2021), 'The Legacy of Birgitta of Sweden: Women,
politics and reform in Renaissance Italy', onder leiding van Unn Falkeid (cf. 2019:93 [vn.32]) en gesubsidieer deur die Noorweegse Navorsingsraad, ondersoek. Die projek sal ongetwyfeld verdere impetus verleen aan Birgitta se profiel in die bestaande navorsingsdomeine van vroulike Middeleeuse filosowe en Laatbestaande navorsings
Middeleeuse filosofie. die handelsroete tussen Noord- en Suid-Europa, met 'n veel beter klimaat as die warm malariageteisterde Rome. Maar bo alles: Avignon was besonder welaf. Die pousdom sou ekonomies en polities met rasse skrede tydens die sojourn in Avignon vooruitgaan, onder meer bemoontlik deur 'n gesentraliseerde kerkbelastingstelsel wat die institusionele gesag van die kerk en die pousdom self dramaties verhoog het. Avignon self het gevolglik in'n kosmopolitaanse sentrum ontwikkel wat 14 de-eeuse Rome by verre oortref het en 'n interkulturele tuiste vir intellektuele gebied het, op grond waarvan die eerste ontwikkelinge van 'n filosofiese humanisme juis hier gestalte kon kry (Rollo-Koster 2015:71).

In Avignon het nie net die kerk nie, maar die pousdom as 'n onderskeibare institusie binne die kerk self ryk en magtig geword. Verset teen die pousdom se toenemend gesekulariseerde belange het egter toegeneem, opvallend vanuit die Franciskaanse orde, wat histories noue bande met die pousdom gehad het. Hierdie verset ${ }^{6}$ teen die Avignonpouse sou Franciskaanse denkers in die eerste helfte van die 14de eeu duur te staan kom: minstens 80 prominente Franciskane is tussen 1322 en 1326 geëkskommunikeer, waaronder Ockham (sien Beukes 2020a:II:1155-1170). Die pouslike setel in Avignon het tot 'n ernstige balansversteuring in die geskiedenis van die pousdom gelei: vanaf die vyfde eeu is pous Gelasius I (410-496, pous vanaf 492 tot 496) se onderskeid tussen tydelike of 'sekulêre' en 'geestelike' mag nougeset as 'n regeringsmodel en die basis vir politieke teorie gehandhaaf, reeds van toe af bekend as die 'twee magte'.

6.Die Franciskane was in die vroeë 14 de eeu in ' $n$ algehele en skynbaar onoplosbare konfrontasie met Clemens V se opvolger, Johannes XXII (Jacques D'Euse, 1244-1334, pous vanaf 1316 tot 1334), oor die vraagstuk na die Franciskaanse orde se verstaan van armoede, gewikkel. Dit was ' $n$ betreklik eenvoudige kwessie: wanneer ' $n$ leerling tot die Franciskaanse orde toegetree het, het daardie leerling afstand gedoen van sy private boedel en dit in toto aan die orde toevertrou, met afstanddoening van eiendomsreg. Baie Franciskane was uit die Europese adelstande afkomstig en daardie boedels was dikwels indrukwekkend. Die toetredende monnik se boedel was dus ineens geoormerk vir usus fructus, oftewel vruggebruik deur die orde. Die Franciskane het met hierdie werkswyse privatregtelike eiendomsre afgewys, maar wou die saaklike reg van vruggebruik - ter wille van die ondernsreg afgewys, maar wou die saaklike reg van vruggebruik - ter wille van die onderhoud en instandhouding van die orde (wat eiendomsregtelik oor geen eiendom beskik het nie, maar 'n studium per stad vir verblyf en onderrig gehuur het) - handhaaf. Johannes XXII het geoordeel dat daardie individuele boedels van toetredende leerlinge die pouslike boedel moes toeval. Ockham bots vanaf 1323 tot 1328 konstant oor hierdie saak met die pous: die eerste deel van die vraagstuk sou hande oor Christus en die apostels se posisie ten opsigte van privaat eiendomsbesit en die tweede deel oor die Franciskane se bogenoemde posisie ten opsigte van 'slegs vruggebruik'. Franciskus self het natuurlik 'n ekstreme armoede-ideaal nagestreef die eerste Franciskane (vroeë-13de eeu) mag niks persoonlik besit het nie, mag letterlik nie aan geld geraak het nie en moes volledig van 'aalmoese' (nie-geldelike ondersteuning) afhanklik wees ten opsigte van lewensonderhoud en huisvesting. Bonaventura (1217-1274), die voormalige en gesaghebbende hoof van die orde, het aan die einde van die 13de eeu 'n uitdruklike onderskeid tussen dominium of usus pauper en usus getref: Franciskane kon wel eiendom gebruik (usus), maar nie individueel of kollektief as ' $n$ orde besit (dominium, usus pauper) nie. In 1279 het individue Nikous III op grond van Bonaventura se posisie, die orde van alle privat pous Nikolaus III, op grond van Bonaventura se posisie, die orde van alle privaat eiendomsbesit onthef en die orde se volledige boedel aan die pouslike patrimonie toevertrou. Aan die einde van 1322 het Johannes XXII Bonaventura se posisie boonop as 'onwerkbaar' en ' $n$ 'skynheilige dwaling' afgemaak, asook die Franciskaanse interpretasie van Jesus en die apostels se posisie ten opsigte van eiendomsreg - warmee die orde se interpretasie van vruggebruik juis wou korrespondeer - as ' $n$ 'dwaling' verklaar. Die hoof van die Franciskaanse orde in 1323, Michael van Sesena, het Ockham versoek om hierdie twee dwalingsdekrete te ondersoek. Ockham het na ondersoek bevind dat die dekrete van Johannes XXI immoreel, absurd en self ketterend van aard was en sy bevindinge publiek gemaak. 'n Pouslike bul vir hulle arrestasie is uitgereik en saam met Sesena moes Ockham saam met tientalle ander Franciskane - vanuit Avignon vir hulle lewens vlug. Hulle het asiel verkry in Duitsland onder keiser Lodewyk van Beiere, wat Johannes XXII as ' $n$ aartsvyand beskou het omdat Johannes Lodewyk se verkiesing as keiser betwis en probeer ondermyn het, deur die troon in 1317 per pouslike dekreet 'vakant' te verklaar. Lodewyk, wat self geëkskommunikeer is in 1324, het hom tot ' $n$ algemene verklaar. Lodewyk, wat self geeekskommunikeer is in 1324, het hom tot ' $\mathrm{n}$ algemene Roomse konsilie gewend om Johannes self as ketter verklaar te kry. Sonder enige uitkoms elders, het Lodewyk Rome in 1328 binnegevaar, homself as Roomse keiser aangestel en ' $n$ keiserlike antipous aangewys. In Rome is Lodewyk dadelik deur ' $n$ filosofiese geesgenoot, Marsilius van Padua, voormalige rektor van die Universiteit van Parys (1312-1313), bygestaan. Johannes XXII se optrede teenoor die Franciskane in die 1320's was net een voorbeeld van die soort politieke vergrype wat vanuit die pouslike setel in Avignon aan die orde van die dag was. 
Pous Bonifatius VIII se berugte bul Unam sanctam van 1302 (sien infra) het reeds voor die verskuiwing van die pouslike setel na Avignon deur sy opvolger Clemens $\mathrm{V}$ tot 'n nuwe aanspraak gelei, naamlik absolute pouslike mag (plenitudo potestatis), wat verbete deur elke pous vanuit Avignon na Clemens V se dood verdedig is. Hierdie balansversteuring het ernstige intellektuele konfrontasies tot gevolg gehad, wat gewissel het vanaf Augustiniaanse monnike soos Gilius van Rome (1243-1316; Beukes 2020a:II:873-882) en Jakobus van Viterbo (ca. 1285-1307; Beukes 2020a:II:951-956) se verdediging van absolute pouslike gesag in onderskeidelik De ecclesiastica potestate (1301) en De regimine Christiano (1302), tot Johannes van Parys (Quidort, sien voetnoot 10 infra), Dante (se Monarchia, ca. 1318; Beukes 2020a:II:983) en Marsilius van Padua se Defensor pacis (1324; Beukes 2020a:II:1183-1192) se aanvegting van plenitudo potestatis. Birgitta se politieke aktivisme hoort in laasgenoemde kader: Avignon is die verhoog waarop haar politieke drama afspeel.

\section{Birgitta, Clemens VI en simonie}

Reeds vroeg in LCR (Birgersdotter 2006:I:23), ${ }^{7}$ waarskynlik geskryf net na haar aankoms in Rome in 1349, vaar Birgitta vlymskerp uit teen 'n eminente kerklike amptenaar, wie sy nie uitdruklik identifiseer nie maar weldra blyk die diensdoenende pous te Avignon (Clemens VI, nogeens, Pierre Roger, 1291-1352, pous vanaf 1342 tot 1352) te wees:

Mense dink dat hy 'n smaakvol gedresseerde, sterk en waardige man is, aktief in diens van die strydvoeringe van die Heer. Wanneer sy hoofbedekking egter afgehaal word, is hy weersinwekkend om na te kyk en duidelik onbevoeg vir enige werk. Sy harsings is ontbloot, sy ore sit teen sy voorkop en sy oë sit teen sy agterkop. Sy neus is afgesny. Sy wange is ingesonke soos dié van 'n dooie. Aan die regterkant van sy gesig het sy wangbeen en lippe weggeval, met niks anders om te sien as ontblote tande en ' $n$ dooie keel nie. Sy bors is vol wriemelende wurms; sy arms is soos twee slange. 'n Bose skerpioen nestel teen sy hart en sy rug lyk soos warm kole. Sy ingewande stink en is verrot soos septiese weefsel; sy voete is dood en nutteloos om mee te probeer loop (Birgersdotter 2002:I:23). ${ }^{8}$

Hierdie dramatiese beeld is 'n bitter en snydende aanklag teen korrupsie en pligsversuim, waarmee Birgitta die verwording van die kerk en veral die selfkoesterende pousdom in die 14de eeu konfronteer: waar die pous as minister Dei sedert die middel van die derde eeu met

\footnotetext{
7.Verwysings na Liber celestis revelaconium geskied per jaar van die Morris-redigering (Birgersdotter 2006, 2008, 2012, 2015), gevolg deur die volume (I-VIII) en
hoofstuknommer van die betrokke volume. Vir direkte aanhalings of woordelikse hoofstuknommer van die betrokke volume. Vir direkte aanhalings of woordelikse
verwysings (per vertaling) word slegs die jaar en bladsynommers verskaf. Wanneer dit uit die konteks duidelik blyk dat ' $\mathrm{n}$ verwysing na LCR gemaak word, word 'Birgersdotter' nie by elke sodanige verwysing uitgeskryf nie.

8.Straubhaar (2002:309-310) dui oortuigend aan dat Birgitta in foutlose, nieskolastiese Latyn geskryf het. Vergelyk byvoorbeeld: 'llle talis videtur hominibus quasi homo bene ornatus, fortis et decorus et in pugna domini sui strenuus sed, amota galea a capite eius, est abhominabilis as videndum et inutilis ad operandum. Apparet enim cerebrum eius nudum. Aures habet in fronte, oculos in occipite. Nasus eius absiscus est. Gene eius ex toto contracte quasi hominis mortui. Maxilla eius ex dextera parte cum faucibus et dimidietate labii toto deciderat, it quod nichil ex dextera parte cum faucibus et dimidietate labii toto deciderat, it quod nichil ex
edextera parte remanent nisi guttur solum, quod nudum apparet. Pectus eius edextera parte remanent nisi guttur solum, quod nudum apparet. Pectus eius
plenum est vermibus scaturientibus, brachia eius quasi duo serpentes. Cor impletum plenum est vermibus scaturientibus, brachia eius quasi duo serpentes. Cor impletum
est pessimo scorpione, dorsum eius velut combustus carbo. Intestina eius sunt fetencia et corrupta quasi caro habundans sanie, pedes eius mortui et inutiles ad fetencia et corrupta quasi caro habundans sanie, pedes eius mortui et inutiles ad
incedendum' (skrywer se vrye vertaling in die hoofteks; cf. Falkeid 2019:80 [vn.1]; cf. Birgersdotter 2006:1:23:89-91).
}

martelaarskap ter wille van die arm en vervolgde gelowiges in Rome geassosieer is, is daardie historiese martelaarsetel in Rome verruil vir die weelde van Avignon. Clemens VI het ook Birgitta se skriftelike versoek vroeg in 1349 om die setel te Avignon te ontruim en terug te keer Rome toe, met minagting verwerp. Birgitta en Clemens VI was van daar af tot en met sy dood in 1352 openlike vyande.

Politiek was vir Birgitta geen geleentheidsbelangstelling nie: ${ }^{9}$ Bogenoemde aanhaling illustreer juis haar kennis van Laat-Middeleeuse politieke retoriek. Die beeld van die misvormde kop is 'n duidelike teruggrepe na Johannes van Salisbury se metaforiese liggaamspolitiek in Policraticus (1159), (Beukes 2019d:6; cf. Le Goff 1989:13), waar die prins as die 'kop' van die staat (res publica) voorgestel word. 'n Halfeeu voor Birgitta se openbare optrede het pous Bonifatius VIII (Benedetto Caetani, 1230-1303, pous vanaf 1294 tot 1303) hierdie politieke beeld in sy direkte konfrontasie met die Franse koning, Phillip IV (le Bel of 'die skone', 1268-1314), egter regstreeks op die pousdom van toepassing gemaak deur middel van die berugte pouslike bul Unam sanctam van 1302: ${ }^{10}$ in 'n ommekeer van Salisbury se liggaamspolitiek verklaar Bonifatius dat die pous nie alleen die hoof van die kerk is nie, maar ook die hoof van alle wêreldse prinse en heersers. Die pous se gesag is absoluut in sowel godsdienstige en sekulêre aangeleenthede, byeengebring in die hiërargiese en hiërokratiese metafoor van die caput of 'kop'. Dit is om hierdie rede dat Birgitta se kritiese beeldspraak vertrek neem vanuit die monstrositeit van hierdie misvormde kop aan 'n verrottende liggaam.

9.Reeds in die vroee 1340 's, nog tydens haar verblyf as weduwee in die Cistersianse klooster te Alvastra, het Birgitta haarself uitermate ongewild gemaak deur' $n$ kritiese verset teen dienstigheid aan materiële rykdom: vergelyk haar snydende kritiek teen die ab Ragnvald van Alvastra, wat (teen vergoeding) 'n ryk persoon wat onde kerklike ondersoek gestaan het of moontlik reeds geëkskommunikeer was, kerklik begrawe het (LCR:I:72:13, cf. vn.4): 'Hy het gesondig teen die Vader, wat ons gelee het om nie partydig te wees ten opsigte van ryk mense of hulle te bevoordeel nie. Birgitta se weersin in materiële welvaart en haar proto-sosialistiese aanvoeling ten opsigte van die onreg gebonde aan die oneweredige verspreiding van goedere in die opsigte van die onreg gebonde aan die oneweredige verspreiding van goedere in die samelewing verskyn vanaf die middel 1340 's as ' $n$ kritiese motief in haar werk (vgl. uit LCR I-III [Birgersdotter 2006]: 1:73:14, 'Mense wat God om die verkeerde rede dien'; 1:74:15, 'Die koning met twee skatte'; I:80:17, 'Die gierige ridder'; I:136:48, 'Priesters as afgodedienaars'; I:160:59, 'Die vernietigde kudde en die roekelose herder'; II:209:14, 'Die goudsmid en die tien talente'; III:277:11, 'Die biskop wat hom soos ' $n$ aap gedra, agter blink en stink aan'; III:289:15, 'Die biskop as 'n steekvlieg'; III:294:18, 'Eietydse Dominikane wat hulle eie ordereëls versaak', III:304:22, 'Die Benediktynse ab wat teen die borste van straatvroue nestel' en III:314:28, 'Vier stede en vier soorte liefde').

10.Vergelyk in hierdie konteks die invloed van Johannes van Parys (ca. 1255-1306, oftewel Jean Quidort, met die sobriquet Surdus, 'die roekelose'; cf. Beukes 2019e:109-112), wat die tweede Laat-Middeleeuse filosoof was wat effektief in politieke filosofie gespesialiseer het, nadat Salisbury se provokatiewe Policraticus meer as ' $n$ eeu vantevore (1159) verskyn het. Quidort het berugtheid verwerf vir sy uitdagende en inderdaad 'roekelose' polities filosofiese werk, De potestate regia et uitdagende en inderdaad 'roekelose' polities filosofiese werk, De potestate regia et
papali (Oor koninklike en pouslike mag) op grond van sy ideologiese ondersteuning papali (Oor koninklike en pouslike mag) op grond van sy ideologiese ondersteuning
van Phillip IV se dispuut met Bonifatius VIII rondom eiendomsreg en die saaklike van Phillip IV se dispuut met Bonifatius VIII rondom eiendomsreg en die saaklike
onderskeid tussen pouslike en koninklike gesag. Strydlustig soos wat De potestate onderskeid tussen pouslike en koninklike gesag. Strydlustig soos wat De potestate
regia et papali was, het die werk 'n belangrike rol in opvolgende Middeleeuse regia et papali was, het die werk ' $n$ belangrike rol in opvolgende Middeleeuse
politieke denke gespeel en was hoogs waarskynlik ook aan Birgitta bekend. Quidort politieke denke gespeel en was hoogs waarskynlik ook aan Birgitta bekend. Quidort filosofiese gronde: hy (1969:96) argumenteer naamlik dat die Christendom gebaseer is op twee wedersyds outonome beginsels, naamlik die natuur, wat tydelike institusies soos ' $n$ monargie bemoontlik (ook in voor-Christelike en nieChristelike beskawings en kulture) en die openbaring, wat kerklike gesag en die institusionele funksies en werkinge van die kerk bemoontlik. Volgens Quidort (1969:98) is hierdie twee ruimtes of beginsels nie regstreeks of direk van mekaar afhanklik nie, maar is as komplemente van dieselfde oogmerk aan mekaar verbind naamlik om die mensheid te begelei tot sowel ' $n$ tydelike welsyn (en ' $n$ sin vir of verstaan van 'sosiale welsyn') as die ewige verlossing. Die tydelike of naturlike element word nie deur die openbaring of ewige element tot stand natuurlike element word nie deur die openbaring of ewige element tot stand gebring of begrond nie - beide kom van God, maar nie een van die twee kom voort uit di ander nie (1969:103). Opvallend verwerp Quidort $(1969: 104,148)$ hier Aquinas se bekende teoretiese posisie dat die pous in staat behoort te wees om die monar wel te kan vermaan, opdragte te kan gee en selfs te kan tug. Vir ' $n$ keurige Engelse vertaling uit Latyn, sien Watt (1971). Sien Bladsyverwysings korrespondeer met die vertaling. 
Vanuit die basismetafore van misvorming en verrotting konfronteer Birgitta die kerklike en sekulêre regerings van die 14de eeu: LCR bevat (implisiet) net soveel politieke kommentaar as teologiese en mistieke eksposisies, hoewel Birgitta se teologie en mistiek nie naastenby die intensiteit en aktivisme van haar politieke denke geëwenaar het nie (Falkeid 2019:81). Nog voordat sy haarself in Rome in 1349 gevestig het, het sy reeds die regime van koning Magnus Eriksson van Swede en sy beplande kruistogte na Rusland (met verbygaan van 'n kruistog na Jerusalem; 2012:VII:16) asook sy belastingbeleid skerp gekritiseer, haar intens bemoei (2012:VI:63) met die verdiepende konflik tussen Engeland en Frankryk wat twee dekades later tot die Honderdjarige Oorlog (1337-1453) sou lei, die pousdom openlik verkwalik vir die oorloë tussen die pouslike state in Noord-Italië, die magsvergrype van die hertog van Milaan ontbloot, die monargieë van Napels vir hulle immoraliteit en poligamieë die stryd aangesê, die koningin van Ciprus (Eleanore van Aragon en haar seun Petrus II), die prins van Antiogië en koningin Johanna van Napels se internasionale beleidstandpunte gekritiseer $(2012$ :VII:7,18) en haar met onverdrote ywer toegespits op die hervorming van die kerk, waarvan die eerste stap vir haar die herstel van die pouslike setel vanaf Avignon na Rome was. Ten grondslag van Birgitta se politieke aktivisme vestig hierdie enkele sentrale oogmerk: die herstel van Rome as die politieke en institusionele sentrum van die Christelik Latynse Weste.

Soos vir Katharina van Siena (Beukes 2021:5-8; cf. Birgersdotter 2012:VII:7) begin die herstel van die pouslike setel na Rome en die algemene hervorming van die kerk eerstens met kritiek op die luukse lewe wat die pouse, kardinale, biskoppe en selfs gewone priesters hulle veroorloof het. Daarby voeg Birgitta (Birgersdotter 2012:VII:7) 'algehele immoraliteit' (waarskynlik verwysend na die wegkalwing op die seksuele moraal in talle Franse kloosters in die 14de eeu; Beukes 2020c:3). In die vierde volume van LCR (Tractatus de summis pontificibus, 2008:IV:237-239) kritiseer sy onder meer 'priesters wat die wêreld liefhet', die 'sleutel verloor het', die 'regverdige man het in 'n bose man laat ontaard' en 'erger as Judas, Christus verkoop en uitverkoop het'. Hier het Birgitta ongetwyfeld simonie ${ }^{11}$ in gedagte, waarop sy in die volgende hoofstuk van LCR (IV) voortborduur deur die korrupsie tot in die hoogste strukture van die kerk deur te trek:

Hulle is almal roofagtige wolwe, skaamteloos [...] onvas soos 'n steen in 'n wankelrige muur [...] soos diewe in die donker [...] immoreel soos straatvroue [...] vuil soos teer, wat almal besmeer wat met hulle in aanraking kom [...] afstootlik soos braaksel [...] pervers soos iemand wat die eie urine drink. (bl. 239-242)

Hoewel hierdie en dergelike uitsprake rondom simonie grof op die moderne oor val, verskil dit nie van die ewe robuuste taalgebruik van 'n laat 13de-eeuse Franciskaanse kritikus soos Petrus Olivius (ca. 1248-1298) nie: Birgitta vind trouens eksplisiet by Olivius se radikale opvattinge rondom

11.Verwysend na die omkoop van priesters vir absolusie of ander dienste wat formeel en informeel met die ampswerk van priesters saamgehang het; asook die koop van
kerklike posisies self, vanaf biskopdomme tot kanselierskappe. Priesterlike korrupsie kerklike posisies self, vanaf biskopdomme tot kanselierskappe. Priesterlike eiendomsregtelike kwessies aansluiting (Falkeid 2019:86). Dit was juis Olivius se radikale pleitbesorging vir die filosofiese waarde van die Franciskaanse opvatting van armoede (wat rééds 'n uitermate intellektuele verheerliking van persoonlike en kollektiewe armoede in die latere Middeleeue was; Flood 1971:13), wat hom van sy Franciskaanse fratres onderskei het, maar ook Birgitta vyf dekades later beïnloed het: waar die laat 13de-eeuse Franciskane kenmerkend gekant was teen dominium (of usus pauper [Burr 1989:17]; dit is dus 'persoonlike' sowel as 'kollektiewe' eiendomsreg), maar suiwer usus of 'vruggebruik' wel positief oorweeg het, was Olivius gekant teen elke moontlike inhoud van beide begrippe. Olivius argumenteer dat die gebruik van lewensmiddele noodsaaklik is sonder om op enige saaklike reg, veral eiendomsreg, daaromtrent aanspraak te kan maak, of selfs formeel terug te kan leun op die meer soepel juridiese begrip van vruggebruik of usus. In hierdie opsig skei sy weë van die Franciskaanse orde se nuansering van usus as 'verantwoorde en nieuitbuitende gebruik' (soos per vorige voetnota aangedui, ook Ockham het hierdie onderskeid drie dekades later in sy konfrontasie met Johannes XXII nog presies so gebruik). By Olivius is die afwysing van selfs usus egter takties: dit staan ten dienste van 'n veel omvangryker maatskaplike beweging, wat binne Franciskaanse geledere as die 'geestelike hervormingsbeweging' bekendgestaan het, ingevolge waarvan slegs nie-materiële dinge in staat is om 'n geldige filosofies teologiese aanspraak te rig. ${ }^{12}$

Dit is presies hierdie geestelike hervormingsbeweging waarby Birgitta (Birgersdotter 2008:IV:242-245) aansluiting vind: dit word in die vierde volume van $L C R$ algaande duideliker dat sy eiendomsreg sowel as vruggebruik deur priesters (op elke vlak) afwys. Priesters kan in hulle 'absolute vryheid' kies om die eie vryheid op te offer en daarmee die opgawe tot absolute gehoorsaamheid aan God te aanvaar, om daarmee elke vorm van eiendomsreg prys te gee, persoonlik en kollektief (cf. Birgersdotter 2015:126 ['Christus verbied die eienaarskap van privaat besittings']; 138 ['Verbod op die aanvaarding van geskenke']. Binne die weelderige konteks van Avignon sou Birgitta se kritiese aansluiting by Olivius, soos geformuleer in 'n brief aan Clemens VI (Birgersdotter 2008:IV:245-246), binne die konteks van simonie eger op dowe ore val. Sy het haar trouens met die

12. Hierdie beweging het self weer ten grondslag daarvan die ontwikkeling van ' voor-moderne teorie van subjektiewe regte (teenoor die objektiewe reg), wat in oor-moderne teorie van subjektiewe regte, wat in moderne poitiekrivius kan wil' wil': die natuurlike orde van dinge impliseer egter geen sodanige subjektiewe regte nie. Die subjektiewe regte moet toegeëien word en moet juis daarom binne die konteks van ' $n$ grondige geestelike verantwoording geskied. Olivius nuansee hierdie posisie juis oordrewe Franciskaans: ideale armoede behoort gebaseer te wees op die moontlikheid en vermoë om vanuit die vrye wil die eie vryheid te versaak - wat die mees die kosbare gawe is waaroor enige mens beskik en wat die mees elementêre basis van menswees of, om die voorkeurbegrip onder Franciskane te gebruik, 'persoon-heid' is of kan wees. Deur die eie vryheid op te offer, aanvaar die Franciskaan volgens Olivius die opgawe tot absolute gehoorsaamheid aan God - en gee daarmee elke vorm van eiendomsreg prys, persoonlik en kollektief. Dit beteken volgens Olivius egter nié ' $n$ absolute onderwerping aan enige vorm van kerklike gesag nie, maar dat 'gehoorsaamheid' eenvoudig 'n gewetensaak behoort kerklike gesag nie, maar dat 'gehoorsaamheid' eenvoudig ' $n$ gewetensaak behoor te wees. Olivius dink oor hierdie verset teen die onderwerping aan kerklike gesag in toenemend dringende, apokaliptiese terme: dit bring hom daartoe om anvanklik gedemp, maar later openlik te verkondig dat die Antichris uit die pousdom afkomstig sal wees, wat vir hom simptomaties was van die strukturele en institusionele verval van die kerk van die laat 13de eeu. Die filosofiese waarde wat die Franciskaanse armoede-ideaal verteenwoordig, is dat dit juis as 'n 'suiwer geestelike hervorming' in die pad staan van die opgang van die pous-as-Antichris. 
aansluiting by 'n radikale kritikus van die pousdom soos Olivius ernstig blootgestel. Dit is nie oordrewe om te beweer dat Birgitta reeds in die jare 1351 tot 1352, op grond van haar politieke aktivisme in lewensgevaar verkeer het nie (Rychterová 2019:248).

Na die spandabelrige Clemens VI se dood het Birgitta gepoog om ook sy opvolger, Innocentius VI (1282-1362, Étienne Aubert, vyfde pous van Avignon, 1352-1362), te beïnloed om die setel te Avignon te ontruim, deur weer die kwessie van simonie en die weelderigheid te Avignon as basis vir haar aandrang aan te bied. Haar verhouding met Innocentius was egter van meet af aan gespanne en Birgitta sou hom uiteindelik verkla vir die 'vervolging van Christene' en die 'aftakeling van kerk en samelewing' (McBrien 2000:242). Dit was uiters ongewoon dat 'n leek - boonop 'n vrou - hierdie soort kritiek teenoor die setel te Avignon kon uitspreek sonder summiere ekskommunikasie. Dit dui egter op die invloed wat Birgitta in slegs die dekade tussen 1349 en 1362 vanuit Rome begin uitoefen het.

\section{Terug na Rome! Birgitta se korrespondensie met Urbanus V en Gregorius XI}

Innocentius se opvolger te Avignon, Urbanus V (1310-1370, Guillaume de Grimoard, pous vanaf 1362 tot 1370) was inderdaad lugtig vir Birgitta se invloed (cf. McBrien 2000:246) en het sorg getref vir 'n minder gespanne verhouding met die politieke aktivis as sy twee voorgangers, vergestalt daarin dat hy op grond van Birgitta se versoek (Birgersdotter 2008:IV:247) die klooster in Vadstena in 1370, 24 jaar na die stigting daarvan, van die voorlopige maar wesenlike pouslike sanksie (synde konformerend aan die Augustiniaanse Ordereëls) voorsien het. Met die bemiddeling van Nicolo d'Orsini, die pouslike landgoedbestuurder in Perugia, kon Birgitta daarin slaag om ' $n$ beduidende aantal van haar openbaringe en mistieke visioene met die pous te deel en het met ' $n$ uitdagende brief in 1370 bykans daarin geslaag om die pous te verhoed om weer finaal na Avignon terug te keer, nadat hy vanaf 1368 tot 1370 wel voorlopig teruggekeer het na Rome. Op grond van die politieke spanning tussen Urbanus $\mathrm{V}$ en die keiser van die Heilige Romeinse Ryk, Karel IV (Wenceslaus, 1316-1378) is Birgitta in 1368 'n buitengewone oudiënsie met Karel IV toegestaan, in die keiser se hoop dat Birgitta wel die konflik tussen die kerk en staat effektief sou kon aanspreek. Hoewel Birgitta die oudiënsie grootliks gebruik het om die keiser oor sy 'morele tekortkominge' aan te spreek, het sy wel daarin geslaag om die spanning tussen die keiser en die pous te ontlont in die laaste maande van 1368. Karel IV het hierna 'n uitgesproke ondersteuner van Birgitta geword: hy het onder die eerste ontvangers van 'n eksemplaar van LCR getel en het die petisie om haar kanonisering in 1377 persoonlik onderteken (cf. Morris se kommentaar [Birgersdotter 2015:10]). Dit is 'n merkwaardige getuigskrif vir hierdie Noord-Europeër wat haar binne minder as twee dekades in die binnekringe van die twee hoogste uitvoerende ruimtes van die kerk en staat in Europa bevind het.

Dit is egter die ongeduldige en uitdagende trant van die brief in 1370 (Birgersdotter 2008:IV:248) aan Urbanus V wat die aktivisme daarvan stempel. Birgitta profeteer naamlik Urbanus $\mathrm{V}$ se dood indien hy wel finaal na Avignon sou terugkeer. Dit blyk ook uit die brief duidelik dat Rome vir Birgitta geheilig is deur die lyding en martelaarskap van Christene in die stad sedert die teregstelling van die apostel Petrus self. Die rol wat Rome in die ontvouing van die Christelike heilsgeskiedenis speel, is vir haar wesenlik, des te meer op grond daarvan dat Jerusalem nou reeds vir 'n halfeeu onder Moslem-beheer gestaan het (die laaste hawe, Acre, is ingeneem reeds in 1291). Die enigste wyse waarop Rome dieselfde lot as Jerusalem gespaar sou bly, sou volgens Birgitta wees indien die pouslike setel daar hervestig word. In 'n herhaling van die metaforiese liggaamspolitiek ten opsigte van Clemens VI se 'misvorming en verrotting', stel Birgitta (Birgersdotter 2008:IV:248-249) in die brief - wat weer wyd gesirkuleer is - dat ' $n$ wrede lot Urbanus $V$ by Avignon inwag: sy tande sal uitgeslaan word, hy sal vinnig blind word en onophoudelik begin bewe. Die feit dat Urbanus aan die druk van sy kardinale toegegee het en wel teruggekeer het Avignon toe, waar hy inderdaad binne maande daarna na 'n pynlike siekbed oorlede is, het Birgitta se gesag as profetiese figuur beduidend versterk (Falkeid 2019:88). Hierdie brief - een van vele waarin Birgitta die pous openlik onder druk geplaas het - word inhoudelik gekomplementeer deur haar aandrang op die algemene hervorming van die kerk (bv. Birgersdotter 2008:IV:149-151). Die herstel van die pouslike setel in Rome en die algemene hervorming van die kerk is vir haar keerkante van dieselfde munt.

Hierdie jukstaposisie van die herstel van die setel en die hervorming van die kerk word herhaaldelik beklemtoon in Birgitta se korrespondensie (Birgersdotter 2008:IV:249-258) met Urbanus V se opvolger, Gregorius XI (1329-1378, Pierre Roger de Beaufort, pous vanaf Desember 1370 tot 1378), waar sy ook die nuwe pous met die dood dreig (Birgersdotter 2008:IV:250) indien hy in Avignon sou bly. Sy vergelyk Gregorius met'n verlamde man (2008:IV:253) en stel hom voor 'n reeks aanklagte (2008:IV:254-256): Simonie en die steel van kerklike eiendom wat (na Olivius se argument) in die eerste plek nooit veronderstel was om kerklike 'eiendom' te wees nie, maar in 'gehoorsaamheid aan God met die armes gedeel moes word' (afd.7); Gierigheid, hebsug en 'n aptyt vir luukshede (afd.8); Die 'verwaarlosing van God se kudde' en 'beroerde herderskap' (afd.9); Trots en ydelheid (afd.13), met die uitermate kwetsende aandrang 'Staan vir eens op soos 'n man!' (afd.14). Daarby stel Birgitta dit in hierdie korrespondensie vir die eerste keer reguit: 'Die pousdom gaan skeur onder die hand van tiranne' (gerealiseer in die Avignonpouse se optrede tydens die Groot Verdeling, 1378-1417; Birgersdotter 2008:IV:252). Hierdie uitdagende woorde is nogeens wyd buite die korrespondensie self gesirkuleer: Birgitta was veel meer aktivisties as haar tydgenoot Katharina 
van Siena en haar uitdaging van die Avignon-pouse vanaf Clemens VI algeheel sonder presedent. ${ }^{13}$

\section{Birgitta se konfrontasie met wêreldheersers: 'Die ideale koning'}

Waar Tractatus de summis pontificibus (LCR IV) Birgitta se aktivistiese konfrontasie met die pousdom van Avignon vanaf 1349 tot 1370 (Clemens VI, Innocentius VI, Urbanus $\mathrm{V}$ en Gregorius XI) verwoord het, bring Liber celestis imperatoris ad reges (hier aangedui as LCR VIII, opgeneem in die Morris-redigering en Searby-vertaling in Birgersdotter [2015] en in Engels vertaal as The heavenly Emperor's book to kings) haar konfrontasie met sekulêre monargieë tot uitdrukking, met inbegrip daarvan dat die Avignon-pouse sedert Clemens V se bul van 1302 dus in terme van plenitudo potestatis (absolute pouslike mag) geen verdere onderskeid tussen pouslike en sekulêre mag getref het nie. Liber celestis imperatoris ad reges bied daarom 'n polities teoretiese refleksie oor die (nou verlore) verhouding tussen kerklike en sekulêre mag, met eksposisies oor sowel die 'goeie pous' as die 'ideale koning', met aksent wel op laasgenoemde. In die werk rig Birgitta haar gevolglik op Europese monargieë: sy verwys met toenemende bitterheid terug na die Sweedse koningshuis (Magnus Eriksson en sy Vlaamse koningin Blanche van Namur vir wie Birgitta dekades gelede as onderwyseres opgetree het), maar fokus ook skerp op die twee sleutelfigure in die Honderdjarige Oorlog, Phillip VI van Frankryk en Edward III van Engeland, met haar ondersteuner keiser Karel IV 'n konstante sanksionerende teenwoordigheid.

Ten spyte van Birgitta se herhaaldelike waarskuwings reeds in die vroeë 1340's, het Eriksson met katastrofiese gevolge 'n kruistog rondom 1345 na die Russiese streke oos van die Baltiese see onderneem, met die gevolglike enorme sterftesyfer vererger deur die eerste vlaag van die pes in dieselfde dekade (Morris, in Birgersdotter 2015:9-10). Afgesien daarvan dat Eriksson Birgitta se uitdruklike advies teengegaan het, het hy in geen stadium oorweeg om eerder 'n kruistog na Jerusalem te onderneem nie - wat vir Birgitta wél krities noodsaaklik was. Sedert die mislukte Russiese kruistog het Birgitta die Sweedse koning openlik gekonfronteer oor sy politieke onstabiliteit, 'lafhartige

13.Gregorius XI het wel in 1377, vier jaar na Birgitta se dood, uiteindelik vanuit Avignon na Rome teruggekeer en daarmee die bykans sewe dekades van die pouslike verblyf te Avignon beëindig. Hy het Katharina (in werklik'n buitengewone stap ten opsigte van die posisie van 'n vroulike geestelike in die 14de eeu) in

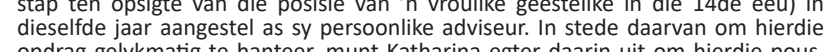
opdrag gelykmatig te hanteer, munt Katharina egter daarin uit om hierdie pous, wat immers die setel teruggeneem het Rome toe, te antagoniseer in haa volgehoue kritiek van wat sy beskryf as sy 'onindrukwekkende politiek en geestelike lusteloosheid' (Von Seckendorff 1917:72). Nietemin stel die pous haar in 1378 aan as pouslike ambassadeur in Firenze, op aandrang van prominente Florentynse staatslui. Gregorius XI is kort daarna oorlede en opgevolg deur Urbanus VI (Bartolomeo Prignano, 1318-1389, pous vanaf 1378 tot 1389), gevolg deur die bykans onmiddellike teenverkiesing van die Franse antipous Clemens VII (Rober de Geneve, 1342-1394). Die Groot Verdeling (1378-1417) wat die kerk teen die einde van die 14 de eeu vir drie dekades lamgelê het, is hiermee van stapel gestuur. Katharina het Urbanus VI se aanwysing eerbiedig en die pous het haar een maa persoonlik in 1379 ontvang, maar uitdruklik verbied om sy ampswerk op dieselfde wyse te kritiseer as wat sy met Gregorius XI gedoen het. Sy het haar nie juis wyse te kritiseer as wat sy met Gregorius XI gedoen het. Sy het haar nie juis daaraan gesteur nie en steeds ongevraagde en aanhoudende advies aan Urbanus VI voorgehou. Urbanus VI het hom aan die einde van 1379 uiteindelik finaal van die jong Dominikaanse non onttrek (Von Seckendorff 1917:149-151). Hy was nie bereid om dieselfde geduld met haar te beoefen as sy voorganger Gregorius XI nie. Nietemin het Katharina se stryd met Gregorius XI en Urbanus VI op geen stadium die aggressiewe politieke aktivisme van Birgitta geëwenaar nie. Dit bly egter merkwaardig dat hierdie twee vroue die angels in die oog van die (ver)skeurende pousdom was. besluite' (Birgersdotter 2015:39), buitensporige kerkbelastings en algemene ekonomiese druk op die kerk, terwyl die Sweedse aristokrasie in weelde bly toeneem het. Na haar aankoms in Rome in 1349, begin Birgitta - ondenkbaar - om steun te monster vir ' $n$ klag van hoogverraad teen die Sweedse koning, deur sowel die laer adel as die Sweedse boerestand op te roep tot opstand teen die koning (Falkeid 2019:94). Hoewel sy daarvan bewus was dat so 'n oproep hoogs waarskynlik nie sou slaag nie, was haar primêre oogmerk om politieke aktivisme - openlike en openbare verset, hetsy teen 'n pous of sekulêre heerser, en ongeag persoonlike gevolge - as 'n haalbare polities filosofiese posisie in die anargistiese $14 \mathrm{de}$ eeu te aksentueer.

Vanuit sodanige aktivisme word 'n politieke idealisme bemoontlik, in terme waarvan die gekritiseerde status quo van geïdealiseerde alternatiewe voorsien kan word. Anders gestel: politieke aktivisme bemoontlik priemende vrae na die oorspronge van politieke mag en die grense van die jurisdiksie van sodanige mag (Wilks 1964:308). Deur aansluiting te vind by ' $n$ verskeidenheid van LaatMiddeleeuse denkers wat die verhouding tussen die twee soorte politieke magte, geestelik en sekulêr, soos wat dit in die latere Middeleeue werksaam was, ondersoek het - onder meer vermelde Quidort, Dante, Olivius en Marsilius van Padua - poog Birgitta om die grense van die twee politieke magte te herkarteer. Ten spyte van haar kenmerkende robuuste en apokaliptiese retoriek, is haar oogmerk nie verdere vervreemding van die twee magte nie, maar om 'n nuwe ekwilibrium tussen die geestelike en sekulêre te artikuleer en wedersydse respek tussen die instellings van beide te bevorder met die pousdom en monargieë as die hoogste 14 de-eeuse uitdrukkings daarvan. ${ }^{14}$

Birgitta (Birgersdotter 2015:VIII:3.1-3.3) se uitgangspunt is dat beide die koning en die pous 'instrumente van God' is. Kenmerkend Augustiniaans Franciskaans argumenteer sy dat die gronde vir die vestiging van sekulêre heerskappy die sondeval is:

Omdat die mens geweier het om God te gehoorsaam, moet die mens 'n ander mens, nie anders die mens self nie, gehoorsaam. Dit is daarom dat God 'n koning aanwys om te oordeel en te regeer in geregtigheid en daarom is dit reg dat' $n$ koning geëer en gerespekteer word deur sy onderdane. Maar juis daarom moet ' $n$ koning uitstaan bo sy onderdane: fyner, meer onderskeie en onderskeibaar as ander mense. Die eer van 'n koning vestig in die toepassing van geregtigheid en gesonde oordeel en die eer van 'n volk om oor 'n onderskeide koning te beskik. Daarom is dit gepas dat 'n koning so aantrek dat hy onderskeibaar is, sonder om ydel oor hierdie voorreg te wees, maar eerder beskeie onder die lading van sy verantwoordelikheid. (VIII:3.1)

Hoewel die mensheid volmaak geskape is, na die beeld van God, was dit die mens se begeerte om self God te wees, wat

14.Vergelyk LCR IV (Birgersdotter 2008:27:3), 'Oor die reg van troonopvolging in 'n land'; 34:5, 'Petrus se klaaglied oor Rome'; 44:10, 'Rome se verval'; 54:16, 'Vergrype in Rome'; 78:33, 'Die klaaglike toestand van Rome en haar ampsdraers', 95:48, "n Koning moet God bo alles eer of sy koninkryk sal verdeel word', 95:49, Vanaf twee kansels klink die aandrang by die pous om die kerk te hervorm" $184: 104$, 'Die konings van Engeland en Frankryk is soos twee roofdiere'; 186:105, "n Voorstel vir vrede tussen Engeland en Frankryk'; en 195:111, 'Kerkreg, keiserlike reg en gemene reg'. 
tot die sondeval gelei het. In hierdie sin is die institusie van die monargie 'n straf vir menslike oormoed. Birgitta (2015:VIII:48) wyk egter af van Augustinus en vind aansluiting by onmiddellike voorgangers soos Aquinas en Dante (wat beide 'n meer positiewe beskouing van sekulêre heerskappy gehad het) deur te argumenteer dat die koning sélf 'n Goddelike roeping het: die koning is deur God aangewys en het daarom enersyds die opdrag om God se geregtigheid in die wêreld van sy onderdane te laat seëvier en andersyds om sy onderdane tot geestelike verlossing te begelei. Dit is die 'ideale koning'.

Opvallend is die detail wat Birgitta (bv. 2015:VIII:4) aan die voorkoms en optrede van die ideale koning skenk: die koning moet stylvol in selfaanbod wees, na kleding en etiket; nooit alleen eet nie, maar altyd saam met onderdane; na etes vir ' $n$ ruk in die geselskap van sy tafelgenote en bediendes bly verkeer; gewillig om na 'gewone godvresende mense' se menings oor selfs komplekse vrae te luister; en bo alles bereid wees om die 'morele kwaliteit van beide sy private en openbare optrede te laat evalueer'. Laasgenoemde sluit aan by Birgitta se politieke troefkaart (binne die konteks van die 14de eeu): daar is geen sprake van 'n ideale koning indien hy nie in die eerste plek 'n 'doodgewone goeie Christen' is nie (2015:VIII:4.14; cf. 4.15-16). Die koning 'moet aan die nagmaalsviering deelneem saam met die plaaslike eenvoudige gemeente', die oordeel van regsinnige kerklike ampsdraers vertrou' en 'barmhartigheid bewys', wat alles aanduidings van sy liefde vir sowel God as die gewone mense in sy ryk is. Die koning is in hierdie sin ' $n$ 'Christelike prins' wat die kerk sal beskerm en opbou - ook juis heropbou, wanneer dit duidelik is dat die 'mure van Jerusalem' (dit is, die Katolieke Kerk self) besig is om in duie te stort. Die koning is uiteindelik niks meer of minder as 'n 'kerklike ridder' nie (2015:VIII:47).

Tog is die koning uiteindelik meer as 'n ridder, naamlik 'n dienskneg (famulus, servus; Falkeid 2019:98) van God (Birgersdotter 2015:VIII:48) en 'n 'vriend van Maria' (amicus; Gilkær [1993:108] wys op die herhaaldelike voorkoms van die begrippe dienskneg en vriend in LCR [cf. 2015:VIII:1, 19, 20, 30, 42, 57; cf. Falkeid 2019:98 \{vn. 47\}]). Beide begrippe gaan ooglopend terug op Augustinus se De civitate Dei (XIV:hfst.29) waar twee vorme van liefde onderskei word, naamlik die liefde vir die wêreldse stad en die liefde vir die stad van God: in eersgenoemde domineer die liefde vir onderwerping en oorheersing, terwyl die liefde vir diens en diensbaarheid in die stad van God botvier, waar die koning soveel dien as wat hy self gedien word. Die sekulêre heerser se politieke sukses word gevolglik bepaal deur sy insig in die grense van sy eie mag: alleen deur homself as 'n beperkte dienskneg te verstaan, kan die monarg regverdig en verantwoordelik heers. Birgitta gaan wel nie sover om na die monarg as vicarius Christi te verwys nie en beperk die gebruik van die begrip konvensioneel tot die pous self (Falkeid 2017:39, 95-120, 2019:99).
Nietemin is die pous se mag self beperk en dus onverantwoordbaar in terme van absolute pouslike mag, soos geproklameer in Bonifatius VIII se vermelde bul Unam sanctam van 1302 . Nie die koning of die pous se politieke jurisdiksie is onbegrens nie: beide se gesag is aan God ontleen en beide is 'niks meer of minder as uitnemende diensknegte (optimus famulus) van God' nie (Birgersdotter VIII:1.26). Beide se gesag word deur Christus, wat die hoogste gesag 'in die hemel en op die aarde is', beperk. Die jurisdiksie oor 'aardse sake' is by die monarg, en oor 'hemelse sake' by die pous gevestig. Anders gestel: Christus self het dit so geordineer dat die wêreld deur 'n dubbele mag beheer word en nie deur die pouslike mag alleen, soos wat Bonifatius VIII in 1302 en die pouse van Avignon vanaf 1309 tot 1370 dit wou hê nie.

\section{Konklusie}

Wanneer die ongekende vaartversnelling in die Birgittanavorsing oor die afgelope twee dekades verreken word, tree hierdie Middeleeuse denker en mistikus inderdaad as 'n politieke aktivis na vore: sy het, vanaf 1349 tot 1373, teen die grein van alle konvensies en met beduidende selfblootstelling 'n venynige kritiek van sowel die pouslike setel te Avignon as sekulêre regeringstelsels van stapel gestuur. Ons vind hier 'n koherente politieke teologie: midde die mistieke eksposisies in haar Liber celestis revelaconium kom uitgebreide politieke kommentaar voor, wat teen die godsdienstige en sosiohistoriese kontekste van die 14de eeu so samehangend moontlik in hierdie artikel uitgewys is. Haar politieke kommentaar dui op Birgitta se insig in en eerstehandse ervaring van die komplekse intriges tussen die kerk, die adelstande en monargieë in Europa in die latere Middeleeue. Birgitta laat blyk ook 'n grondige vertroudheid met gevestigde politieke en teologies filosofiese tradisies vanuit geheel die Middeleeue, reeds sedert Augustinus. Sowel haar praktiese as intellektuele omgang met die manifestasies van daardie tradisies in die $14 \mathrm{de}$ eeu het 'n aktivistiese, maar altyd saaklike argumentvoering teen haar tydgenootlike magshebbers, hetsy die pous, koning of keiser, bemoontlik. Birgitta se pleitbesorging vir die herstel van Rome as die politieke, institusionele en godsdienstige sentrum van die Christendom, haar kritiek teen die pouslike buitensporighede te Avignon en haar proto-Reformatoriese oproep tot die algemene hervorming van kerk, staan sentraal in hierdie aktivisme. Birgitta se politieke kommentaar verskaf 'n wesenlike bydrae tot ' $n$ eietydse herverstaan van die politieke en sosiokulturele landskappe van die 14de eeu. Soos wat die betreklik jong Birgitta-navorsing haar ondergekommentarieerde literêre korpus algaande verder oopdek, word Birgitta Birgersdotter in ons midde gestel as inderdaad 'n 'dogter wie se aangrypende stem oor die wêreld gehoor sal word' - juis ook nog in die 21ste eeu.

\section{Erkenning}

Die skrywer is verbonde aan die Sentrum vir die Geskiedenis van Filosofie en Wetenskap (CHPS), Radboud Universiteit Nijmegen, Nederland. 


\section{Mededingende belange}

Die skrywer verklaar dat hy geen finansiële of persoonlike verbintenis het met enige party wat hom nadelig kon beïnvloed in die skryf van hierdie artikel nie.

\section{Outersbydrae}

J.B. was die enigste skrywer betrokke by die skryf van die artikel.

\section{Etiese oorwegings}

Hierdie artikel volg alle etiese standaarde vir navorsing

\section{Befondsing}

Hierdie artikel is befonds deur die Departement Filosofie, Fakulteit Geesteswetenskappe, Universiteit van die Vrystaat.

\section{Data beskikbaarheidsverklaring}

Data-deling is nie van toepassing op hierdie artikel nie, aangesien geen nuwe data in die studie geskep of ontleed is nie.

\section{Vrywaring}

Die sienings en menings wat in hierdie artikel uitgedruk word, is dié van die skrywer en weerspieël nie noodwendig die amptelike beleid of posisie van enige geaffilieerde agentskap van die skrywer nie.

\section{Literatuurverwysings}

Adams, J., 2016, The revelations of St Birgitta. A study and edition of the Birgittine Norwegian Texts, Swedish National Archives, E 8902, Brill, Leiden.

Andersson, E. (red., inl. en vert.), 2011, Responsiones Vadstenenses. Perspectives on the Birgittine Rule in two texts from Vadstena and Syon Abbey. A critical edition with translation and introduction, Stockholms Universitet, Stockholm.

Andersson, R., 2019, 'Birgitta and her revelations in the sermons of the Vadstena Brothers', in M.H. Oen (red.), A companion to Birgitta of Sweden and her legacy in the later Middle Ages, pp. 159-185, Brill, Leiden.

Beukes, J., 2019a, 'Hildegard von Bingen as 'n 12de-eeuse filosoof-teoloog', Litnet Akademies 16(1), 64-102, besigting 08 Februarie 2020, vanaf https://www.litnet. co.za/wp-content/uploads/2019/06/LitNet_Akademies_16-1_Beukes_64-102.pdf.

Beukes, J., 2019b, 'Héloïse d'Argenteuil se filosofiese uitset', HTS Teologiese Studies/ Theological Studies 75(4), Art. \#5281, 1-12. https://doi.org/10.4102/hts. v75i4.5281

Beukes J., 2019c, “"Maak die wêreld nie tot bespotting nie”: 'n Herwaardering van die filosofiese aspekte in Mechtild von Magdeburg se Das fließende Licht der Gottheit (1250)', Verbum et Ecclesia 40(1), Art. \#1965, 1-8. https://doi.org/10.4102/ ve.v40i1.1965

Beukes, J., 2019d, 'Policraticus en Metalogicon: 'n Bywerking van die Saresberiensisnavorsing, 2013-2018', Verbum et Ecclesia 40(1), Art. \#1959, 1-14. https://doi. org/10.4102/ve.v40i1.1959

Beukes, J., 2019e, 'De potestate regia et papali: 'n "Uuurglas"-bywerking van die mees onlangse Quidort-navorsing', Litnet Akademies 16(2), 109-168, besigting onlangse Quidort-navorsing', Litnet Akademies 16(2), 109-168, besigting LitNet_Akademies_16-2_Beukes_109-168.pdf.

Beukes, J., 2020a, Middeleeuse Filosofie, vol. I \& II, Akademia, Pretoria.

Beukes, J., 2020b, 'The Trinitarian and Christological Minnemystik of the Flemish beguine Hadewijch of Antwerp (fl.1240)', HTS Teologiese Studies/Theological Studies 76(1), Art. \#5865, 1-10. https://doi.org/10.4102/hts.v76i1.5865

Beukes, J., 2020c, 'Intervroulike seksualiteit in die latere Middeleeue: 'n Ideëhistoriese oorsig', Verbum et Ecclesia 41(1), Art. \#2074, 1-13. https://doi.org/10.4102/ ve.v41i1.2074

Beukes, J., 2020d, 'Die eliminering van die siel in die filosofiese mistiek en negatiewe teologie van die begyn Marguerite Porete (1250-1310)', Litnet Akademies 17(2), viewed 08 February 2020, from https://www.litnet.co.za/die-eliminering-van-diesiel-in-die-filosofiese-mistiek-en-negatiewe-teologie-van-die-begyn-margueriteporete-1250-1310/.
Beukes, J., 2020e, 'Juliana van Norwich (1342-ca.1416) as post-skolastiese teoloog', HTS Teologiese Studies/Theological Studies 76(4), Art. \#6001, 1-10. https://doi. org/10.4102/hts.v76i4.6001

Beukes, J., 2021 (in press), 'Die "vyf trane" as mistieke uitdrukking in die Dialoë van die Dominikaanse non Katharina van Siena (1347-1380)', Litnet Akademies 18.

Birgersdotter, B. (Birgitta van Swede), 2006, 'Liber Caelestis I-III', in The revelations of St. Birgitta of Sweden, vol. 1, B. Morris (red., inl. \& komm.), D. Searby (vert.), Oxford University Press, Oxford.

Birgersdotter, B. (Birgitta van Swede), 2008, 'Liber Caelestis IV-V', in The revelations of St. Birgitta of Sweden, vol. 2, B. Morris (red., inl. \& komm.), D. Searby (vert.), Oxford University Press, Oxford.

Birgersdotter, B. (Birgitta van Swede), 2012, 'Liber Caelestis VI-VII', in The revelations of St. Birgitta of Sweden, vol. 3, B. Morris (red., inl. \& komm.), D. Searby (vert.), Oxford University Press, Oxford.

Birgersdotter, B. (Birgitta van Swede), 2015, 'The heavenly Emperor's book to kings, The Rule, and Minor Works', in The Revelations of St. Birgitta of Sweden, vol. 4 B. Morris (red., inl. \& komm.), D. Searby (vert.), Oxford University Press, Oxford.

Bosley, R.N. \& Tweedale, M. (reds.), 2004, Basic issues in Medieval philosophy. Selected readings presenting the interactive discourses among the major figures, Broadview Press, Ontario.

Brown, S.F. \& Flores, J.C., 2007, Historical dictionary of medieval philosophy and theology, The Scarecrow Press, Plymouth.

Burr, J., 1989, Olivi and Franciscan poverty: The origins of the Usus Pauper Controversy, University of Pennsylvania Press, Philadelphia, PA.

Collijn, I. (red.), 1924-1931, Acta et processus canonizacionis b. Birgitte, Samlinagar utgivna as Svenska fornskriftsällskapet, Ser. 2, Latinska skrifter 1, Swedish Medieval Texts Society, Uppsala.

Copleston, F.C., 1993, 'A history of philosophy', Medival pilosophy vol. II, Doubleday, New York, NY.

Debby, N.B-A., 2019, 'Reshaping Birgitta of Sweden in Tuscan art and sermons', in M.H. Oen (red.), A companion to Birgitta of Sweden and her legacy in the later Middle Ages, pp. 223-246, Brill, Leiden.

Falkeid, U., 2017, The Avignon papacy contested: An intellectual history from Dante to Catherine of Siena, Harvard University Press, Cambridge, MA.

Falkeid, U., 2019, 'The political discourse of Birgitta of Sweden', in M.H. Oen (red.), A companion to Birgitta of Sweden and her legacy in the later Middle Ages, pp. 80-102, Brill, Leiden.

Flood, D., 1971, Poverty in the Middle Ages, Coelde Verlag, Werl.

Frediksson, A., 2019, 'Challenging and championing St Birgitta's Revelations at the Councils of Constance and Basel', in M.H. Oen (red.), A companion to Birgitta of Sweden and her legacy in the later Middle Ages, pp. 103-131, Brill, Leiden.

Fritz, B., 2019, 'The history and spiritual life of Vadstena Abbey', in M.H. Oen (red.) A companion to Birgitta of Sweden and her legacy in the later Middle Ages, pp. 132-158, Brill, Leiden.

Gilkær, H.T., 1993, The political ideas of St Birgitta and her Spanish confessor, University Press of Southern Denmark, Copenhagen.

Gracia, J.J.E. \& Noone, T.B. (reds.), 2006, A companion to philosophy in the Middle Ages, Blackwell, Oxford.

Grant, E., 2004, God and reason in the Middle Ages, Cambridge University Press, Cambridge.

Holloway, J.B. (inl., vert. \& komm.), 1992, Saint Bride and her book: Birgitta of Sweden's revelations, Focus Information Group, Newburyport.

Hutchison, A.M., 2019, 'Birgitta and late-Medieval English spirituality', in M.H. Oen (red.), A companion to Birgitta of Sweden and her legacy in the later Middle Ages, pp. 269-288, Brill, Leiden.

Hyman, A., Walsh, J.J. \& Williams, T. (reds.), 2010, Philosophy in the Middle Ages: The Christian, Islamic and Jewish Traditions, Hackett, Indianapolis, IN.

Kenny, A., 2005, Medieval philosophy, Clarendon Press, Oxford.

Kezel, A.R. (red.), 1990, Birgitta of Sweden. Life and selected revelations, Paulist Press, New York, NY.

Klockars, B., 1966, Birgitta och böckerna. En undersökning af den heliga Birgittas källor, Almquist \& Wiksell, Stockholm.

Klockars, B., 1971, Birgitta och hennes värld, Almquist \& Wiksell, Stockholm.

Klockars, B., 1976, Birgittas svenska värld, Almquist \& Wiksell, Stockholm.

Kretzmann, N., Kenny, A. \& Pinborg, J. (reds.), 1982, The Cambridge History of Later Medieval Philosophy, Cambridge University Press, Cambridge.

Lagerlund, H., (red.), 2011, Encyclopedia of Medieval Philosophy. Philosophy between 500 and 1500 , Springer, London.

Le Goff, J., 1989, 'Head or heart? The political use of body metaphors in the Middle Ages', in M. Feher (red.), Fragments for a history of the human body, pt.1, pp. 13-26, Zone Books, New York, NY.

Luongo, F.T., 2019, 'God's words, or Birgitta's? Birgitta of Sweden as author', in M.H. Oen (red.), A companion to Birgitta of Sweden and her legacy in the later Middle Ages, pp. 25-52, Brill, Leiden.

Luscombe, D.E., 1997, Medieval thought, Opus-Oxford University Press, Oxford.

Marenbon, J., 1991, Later Medieval philosophy (1150-1350): An introduction, Routledge, London. 
Marenbon, J. (red.), 1998, Medieval Philosophy. Routledge history of philosophy, vol. III, Routledge, London.

Marenbon, J., 2007, Medieval Philosophy: An historical and philosophical introduction, Routledge, London.

Martin, C.J.F., 1996, An introduction to Medieval Philosophy, Edinburgh University Press, Edinburgh.

McBrien, R.P., 2000, Lives of the Popes, HarperCollins, New York, NY.

McGrade, A.S. (red.), 2003, The Cambridge companion to Medieval Philosophy, Cambridge University Press, Cambridge.

Morris, B., 1999, St Birgitta of Sweden, The Boydell Press, Suffolk.

Morris, B., 2006, 'General introduction', in B. Morris (inl. \& komm.) \& D. Searby (vert.), The Revelations of St. Birgitta of Sweden, vol. I, pp. 3-38, Oxford University Press, Oxford.

Morris, B. \& O'Mara, V., 2000, 'Introduction', in B. Morris \& V. O'Mara (reds.), The translation of the works of St Birgitta of Sweden into the Medieval European vernaculars, pp. 1-24, Turnhout, Brepols.

Oen, M.H. (red.), 2006, A companion to Birgitta of Sweden and her legacy in the later Middle Ages, Brill, Leiden.

Oen, M.H., 2019, 'Birgitta Birgersdotter and the Liber celestis revelaconium', in M.H. Oen (red.), A companion to Birgitta of Sweden and her legacy in the later Middle Ages, pp. 1-24, Brill, Leiden.

Pasnau, R. \& Van Dyke, C. (reds.), 2010a, The Cambridge History of Medieval Philosophy, vol. I, Cambridge University Press, Cambridge.

Pasnau, R. \& Van Dyke, C. (reds.), 2010b, The Cambridge History of Medieval Philosophy, vol. II, Cambridge University Press, Cambridge.
Piltz, A., 2019, 'Birgitta and the Bible', in M.H. Oen (red.), A companion to Birgitta of Sweden and her legacy in the later Middle Ages, pp. 53-79, Brill, Leiden.

Quidort, J. (Johannes van Parys), 1969, De potestate regia et papali, Ernst Klett Verlag, Stuttgart.

Rollo-Koster, J., 2015, Avignon and its Papacy, 1309-1417: Popes, institutions, and society, Rowman \& Littlefield, Lanham, MD.

Rychterová, P., 2019, 'The Revelations of St Birgitta in the Holy Roman Empire', in M.H. Oen (red.), A companion to Birgitta of Sweden and her legacy in the later Middle Ages, pp. 247-268, Brill, Leiden.

Sahlin, C.L., 2001, Birgitta of Sweden and the voice of prophecy, The Boydell Press, Suffolk.

Salmesvuori, P., 2014, Power and Sainthood: The case of Birgitta of Sweden, Palgrave Macmillan, New York, NY.

Straubhaar, S., 2002, 'Birgitta Birgersdotter, Saint Bride of Sweden (1303?-1773)', in L.J. Churchill, P.R. Brown \& J.E. Jeffrey (reds.), Women writing Latin: From Roman Antiquity to Early Modern Europe, vol. 2, Medieval Women Writing Latin, pp. 309-318, Routledge, New York, NY.

Von Seckendorff, E.F., 1917, Die Kirchenpolitische Taetigkeit der heiligen Katharina von Siena unter Papst Gregor IX, Rothschild, Berlin.

Watt, J.A., 1971, John of Paris. On royal and papal power, Pontifical Institute of Mediaeval Studies, Toronto.

Wilks, M., 1964, The problem of sovereignty in the later Middle Ages, Cambridge University Press, Cambridge.

Wolfskeel, C., 1989, 'Birgitta of Sweden', in M.E. Waithe (red.), A history of women philosophers, vol. II, Medieval, renaissance and enlightenment women philosophers, pp. 191-222, Kluwer, Dordrecht. 